Braz J Med Biol Res, February 2012, Volume 45(2) 118-124

doi: 10.1590/S0100-879X2012007500008

Identification of Albizia lebbeck seed coat chitin-binding vicilins (7S globulins) with high toxicity to the larvae of the bruchid

\section{Callosobruchus maculatus}

A.J. Souza, A.T.S. Ferreira, J. Perales, D.G. Beghini, K.V.S. Fernandes, J. Xavier-Filho, T.M. Venancio and A.E.A. Oliveira

The Brazilian Journal of Medical and Biological Research is partially financed by

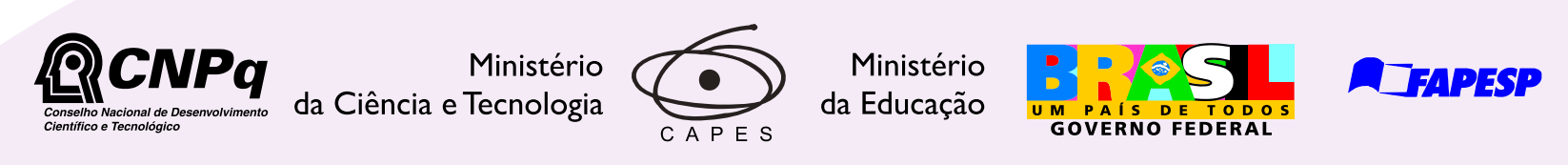

Institutional Sponsors
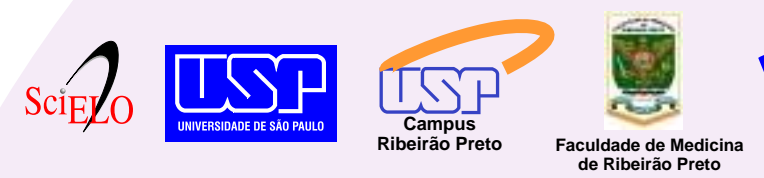
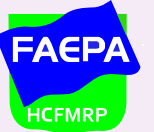

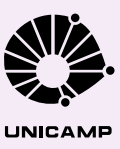

SHIMADZU

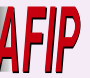

Associaçăo
Fundo de Incentivo
à Pesquisa

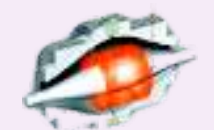

UNICAMP

lore High - Performance MS Orbitrap Technology analitica Thermo 


\title{
Identification of Albizia lebbeck seed coat chitin-binding vicilins (7S globulins) with high toxicity to the larvae of the bruchid Callosobruchus maculatus
}

\author{
A.J. Souza ${ }^{1}$, A.T.S. Ferreira², J. Perales ${ }^{2}$, D.G. Beghini², K.V.S. Fernandes ${ }^{1}$, \\ J. Xavier-Filho ${ }^{1}$, T.M. Venancio ${ }^{1}$ and A.E.A. Oliveira ${ }^{1}$ \\ ${ }^{1}$ Laboratório de Química e Função de Proteínas e Peptídeos, Centro de Biociências e Biotecnologia, \\ Universidade Estadual do Norte Fluminense, Campos dos Goytacazes, RJ, Brasil \\ 2Laboratório de Toxinologia, Departamento de Fisiologia e Farmacodinâmica, Instituto Oswaldo Cruz, \\ Fundação Oswaldo Cruz, Rio de Janeiro, RJ, Brasil
}

\begin{abstract}
Seed coat is a specialized maternal tissue that interfaces the embryo and the external environment during embryogenesis, dormancy and germination. In addition, it is the first defensive barrier against penetration by pathogens and herbivores. Here we show that Albizia lebbeck seed coat dramatically compromises the oviposition, eclosion and development of the bruchid Callosobruchus maculatus. Dietary supplementation of bruchid larvae with A. lebbeck seed coat flour causes severe weight loss and reduces survival. By means of protein purification, mass spectrometry and bioinformatic analyses, we show that chitinbinding vicilins are the main source of $A$. lebbeck tegumental toxicity to $C$. maculatus. At concentrations as low as $0.1 \%, A$. lebbeck vicilins reduce larval mass from $8.1 \pm 1.7$ (mass of control larvae) to $1.8 \pm 0.5 \mathrm{mg}$, which corresponds to a decrease of $78 \%$. Seed coat toxicity constitutes an efficient defense mechanism, hindering insect predation and preventing embryo damage. We hypothesize that $A$. lebbeck vicilins are good candidates for the genetic transformation of crop legumes to enhance resistance to bruchid predation.
\end{abstract}

Key words: Chitin-binding proteins; Seed coat; Callosobruchus maculatus; Insect bruchid

\section{Introduction}

During fruit development, seeds from several plants accumulate proteins, forming a critical nutritional source that is metabolized during germination and seedling growth (1). In eudicot seeds, $7 \mathrm{~S}$ vicilins (globulins) are the main reserve proteins $(1,2)$. In addition to their major role as energy source, alternative functions for vicilins have been proposed in sucrose binding (3), desiccation (4) and defense against insects and fungi (5-8). Several cotyledonary and tegumental vicilins can confer protection against Callosobruchus maculatus (9-12), the sugarcane borer Diatraea saccharalis (13) and Tenebrio molitor (8) larvae. In addition, vicilins isolated from various legume seeds (e.g., Vigna angularis, Phaseolus vulgaris and Glycine max) also impaired C. maculatus larval development (14). Furthermore, the mechanism of vicilin toxicity to some insects has been associated with their chitin-binding properties $(5,6,12-14)$. Chitin is an extracellular amino-sugar polymer of $\mathrm{N}$-acetyl-ß-glucosamine that is an essential structural component of fungal cell walls, exoskeletons and peritrophic membranes (PM; in arthropods) (15). PM is a non-cellular membrane consisting of chitin, proteins, glycoproteins, and proteoglycan conjugates (16). This structure has important roles in the recycling of digestive enzymes and in the protection of the epithelium against food particle abrasion and microorganism infection (16). C. maculatus predation seriously compromises the replanting and commercialization potential of Vigna unguiculata (cowpea) seeds, a key legume crop in the semi-arid tropics. In view of its critical agronomic relevance, we investigated the toxicity of Albizia lebbeck seed coat proteins to C. maculatus. A. lebbeck is a widespread species of the Albizia genus and recent studies have suggested its pharmacological potential as a source for anti-tumor, anti-fungal and anti-inflammatory molecules $(17,18)$. 


\section{Material and Methods}

\section{Seeds and insects}

A. lebbeck seeds were collected at Universidade Estadual do Norte Fluminense, Campos dos Goytacazes, RJ, Brazil. Commercial cowpea (V. unguiculata cv. fradinho) seeds were purchased from local markets at Campos dos Goytacazes, RJ, Brazil. C. maculatus (Coleoptera: Bruchidae) adults were maintained in an in-house colony and reared on cowpea seeds (cv. fradinho) at $28^{\circ} \mathrm{C}, 60-80 \%$ relative humidity, and a 12-h light:12-h dark photoperiod.

\section{Seed infestation}

Sixty $A$. lebbeck seeds were placed in glass flasks and exposed to ten 3-day-old C. maculatus females for $24 \mathrm{~h}$. The experiment was conducted in a BOD incubator chamber at $28^{\circ} \mathrm{C}$ and $70 \%$ relative humidity. Females were removed and larval development was monitored using a stereoscopic microscope coupled to a digital CCD video camera, from oviposition to complete seed coat perforation or larval death. Control experiments using cowpea as host seeds were performed in parallel under the same conditions.

\section{Extraction and purification of seed coat proteins}

Seed coats were separated from cotyledons and ground with a pestle and mortar. Proteins were extracted (1:10 flour to buffer ratio) with $100 \mathrm{mM}$ phosphate buffer with $500 \mathrm{mM}$ $\mathrm{NaCl}, \mathrm{pH} 7.6$, for $3 \mathrm{~h}$ at $4^{\circ} \mathrm{C}$ and centrifuged at $10,000 \mathrm{~g}$ for $30 \mathrm{~min}$. The supernatant was treated with $90 \%$ saturation with ammonium sulfate for $24 \mathrm{~h}$ at $4^{\circ} \mathrm{C}$ and centrifuged at $10,000 \mathrm{~g}$ for $30 \mathrm{~min}$ at $4^{\circ} \mathrm{C}$. The precipitated fraction was dialyzed against water for $24 \mathrm{~h}$ at $4^{\circ} \mathrm{C}$ using $7-\mathrm{kDa}$ cut-off membranes and freeze-dried.

The freeze-dried material was diluted $(500 \mathrm{mg} / 46 \mathrm{~mL}$ $0.1 \mathrm{M}$ sodium acetate buffer, $\mathrm{pH}$ 5.0) and fractionated by CM-Sepharose ion exchange chromatography. The sample was applied to a $2.0 \times 21.0 \mathrm{~cm}$ column equilibrated with 0.1 $\mathrm{M}$ sodium acetate buffer, $\mathrm{pH}$ 5.0. The non-retained fraction $(\mathrm{Cl})$ was eluted and adsorbed proteins were sequentially desorbed using 0.25 and $0.5 \mathrm{M} \mathrm{NaCl}$ solutions (CII and CIII fractions, respectively).

Gel filtration chromatography was used to separate a 50 $\mathrm{mg} / \mathrm{mL}$ (50 mM potassium phosphate buffer, $\mathrm{pH}$ 7.8) sample of Cl on a Sephacryl S-100 column $(2.0 \times 70 \mathrm{~cm})$. The fractions (SI, SII, and SIII) were eluted using the sample dissolution buffer. The SI fraction was used for protein identification and characterization and toxicity to insects.

\section{Protein identification and characterization}

The protein fraction obtained by Sephacryl S-100 gel filtration chromatography (SI fraction) was analyzed by $15 \%$ SDS-polyacrylamide gel electrophoresis (SDS-PAGE) (19), conducted at $15 \mathrm{~mA}$. Gels were stained with $0.05 \%$ Coomassie blue and destained in $10 \%$ acetic acid.

In-gel tryptic digestion of SI fraction proteins was per- formed as described (20). For mass spectrometry analysis the peptides were co-crystallized with $0.3 \mu \mathrm{L} 10 \mathrm{mg} / \mathrm{mL}$ a-cyano4-hydroxycinnamic acid solution in $0.1 \%(\mathrm{w} / \mathrm{v})$ trifluoroacetic acid, $50 \%(\mathrm{v} / \mathrm{v})$ acetonitrile directly onto a MALDI target plate. Raw data for protein identification were obtained with a 4700 Proteomics Analyzer (Applied Biosystems, USA). Both mass spectrometry (MS) and MS/MS data were acquired in the positive and reflectron modes using a neodymium-doped yttrium aluminum garnet ( $\mathrm{Nd}$ :YAG) laser with a $200-\mathrm{Hz}$ repetition rate. Typically, 1600 shots were accumulated for spectra in the MS mode while 3000 shots were accumulated for spectra in the MS/MS mode. Up to 10 of the most intense ion signals with a signal-to-noise ratio above 20 were selected as precursors for MS/MS acquisition. Peptides from trypsin autolysis peaks and matrix ion signals were discarded. External calibration in the MS mode was performed using a mixture of four peptides: desArg1-bradykinin ( $\mathrm{m} / \mathrm{z}=904.47)$, angiotensin I ( $/ \mathrm{z}=1296.69)$, Glu1-fibrinopeptide B (m/z = 1570.68), and ACTH (18-39) $(\mathrm{m} / \mathrm{z}=2465.20)$. MS/MS spectra were externally calibrated using fragments of known ion masses observed in the MS/ MS spectrum of angiotensin I. MS/MS results were searched against the $\mathrm{NCBI} \mathrm{nr}$ databases using the Mascot software (www.matrixscience.com). The peptide sequences were analyzed using the Scaffold $3^{\mathrm{TM}}$ software to determine peptide identification probability. Bit scores were computed by aligning the MS peptides using BLAST. Search parameters were as follows: two tryptic missed cleavages allowed, non-fixed modifications of methionine, tryptophan, histidine (oxidation), cysteine (carbamidomethylation and proprionamide). The pps and ppw files were generated from the raw (or native) MS data according to the following parameters using the Data Explorer Software (Applied Biosystems, USA). For MS1: mass range: 900-4000; peak density: 15 peaks per $200 \mathrm{Da}$; signal-to-noise ratio: 20; minimum area: 100 , and maximum peaks per spot: 60 . For MS2: mass range: 60 and precursor 20; peak density: 55 peaks per 200 Da; signal-to-noise ratio: 2; minimum area: 10, and maximum peaks per precursor: 200 .

\section{Bioinformatic analyses}

We used a computational strategy based on BLAST searches (command line version) (21) to identify the proteins (or close homologs from other species) from which the MS peptides were derived. Since the sequenced peptides are short, we used non-default BLAST parameters (word size 2, no filters or compositional based statistics and PAM30 as score matrix). The full-length amino acid sequences of the aligned hits were submitted to a second BLAST search, which allowed us to obtain a more comprehensive list of homologs, not biased by the short alignments from MS peptides. Sequences aligning with an E-value $<0.001,40 \%$ similarity and $50 \%$ query and hit coverage were recovered, clustered using blastclust (21), and aligned using MUSCLE (22). BLAST results were parsed using BioPerl (23) and custom Perl scripts. Taxonomic information was obtained from the Taxonomy database (NCBI) (24) using custom scripts. 


\section{Feeding trials}

To test the effects of the seed coat flours and chromatographic fractions on larval development, we used an artificial seed system (9). Samples were added to a cowpea-based meal at concentrations of $0.1,0.25,0.5$, and $1.0 \%$. Artificial seeds were exposed to 3-day-old fertilized females for $24 \mathrm{~h}$ $\left(28^{\circ} \mathrm{C}, 70 \%\right.$ relative humidity). Females were removed and laid eggs were left at a concentration of 3 eggs per seed. After 20 days, infested seeds were opened and larvae were counted and weighed. Control experiments were performed under the same conditions using V. unguiculata (cv. fradinho) cotyledons. Experiments consisted of 3 seeds per assay and were run in triplicate (a total of 9 seeds and 27 eggs per tested dose). Statistical significance was assessed using the Student $t$-test $(P$ value $<0.05)(25)$.

\section{ELISA}

Vicilin levels were quantified by enzyme-linked immunosorbent assay (ELISA) (26), using an anti-V. unguiculata (cv. EPACE-10) vicilin antibody produced in rabbits (primary antibody) diluted 1:1000 and a peroxidase-conjugated antirabbit IgG antibody (secondary antibody) diluted 1:2000. Cotyledonary EPACE-10 vicilin samples (5 to $0.0024 \mu \mathrm{g} / 100$ $\mu \mathrm{L})$ were used as reference. Peroxidase activity was developed using ortho-phenylenediamine.

\section{Chitin-binding assay}

Chitin from lobster shells was obtained from SigmaAldrich (USA) and treated with a previously established protocol (27). The finely ground chitin was used to prepare an affinity column, subsequently used to purify chitin-binding proteins from the $\mathrm{Cl}(162 \mathrm{mg} / 2 \mathrm{~mL})$ and $\mathrm{SI}(18 \mathrm{mg} / \mathrm{mL})$ fractions (dissolved in $80 \mathrm{mM}$ sodium acetate buffer, $\mathrm{pH}$ 5.0). The non-retained fraction was eluted with the dilution buffer and adsorbed proteins were desorbed using $0.1 \mathrm{M}$ $\mathrm{HCl}$. Both fractions were dialyzed against water for $24 \mathrm{~h}$ at $4^{\circ} \mathrm{C}$ and freeze-dried.

\section{Results}

\section{Toxicity of $\boldsymbol{A}$. lebbeck seed coat to $\boldsymbol{C}$. maculatus}

By comparing the survival and development of $C$. maculatus on $A$. lebbeck and $V$. unguiculata $\mathrm{CV}$. fradinho (host seed) we found that oviposition, larval eclosion and adult emergence were drastically compromised in the former. The reduction of oviposition was striking (96\%), whereas seed coat penetration, larval eclosion and adult emergency were not observed before 30 days after oviposition. The amount of adults that emerged from the $V$. unguiculata seeds after this time was about $86 \%$ (data not shown).

Additional experiments using flour prepared from $A$. lebbeck seed coats showed a clear dose-dependent toxicity to C. maculatus larvae, with strong weight loss and mortality by 20 days (Figure 1). At concentrations of $0.25,0.5$, and $1 \%$, we observed $40,83.8$, and $87.1 \%$ larval weight loss, respectively. In addition, after 20 days of incubation, only $14.1 \%$ of the larvae survived on a diet with $1 \%$ of $A$. lebbeck seed coat flour $(P<0.05, t$-test).

\section{Purification and characterization of seed coat proteins and toxicity to $C$. maculatus}

A. lebbeck seed coat proteins were initially precipitated using $0-90 \%$ ammonium sulfate and submitted to ion exchange chromatography on a CM-Sepharose column, resulting in a non-retained fraction $(\mathrm{Cl})$ and two adsorbed fractions that were desorbed with 0.25 and $0.5 \mathrm{M} \mathrm{NaCl}$ (CII and CIII, respectively). Higher $\mathrm{NaCl}$ concentrations (0.75 and $1.0 \mathrm{M} \mathrm{NaCl}$ ) did not desorb additional protein fractions (Figure 2). The three chromatographic fractions

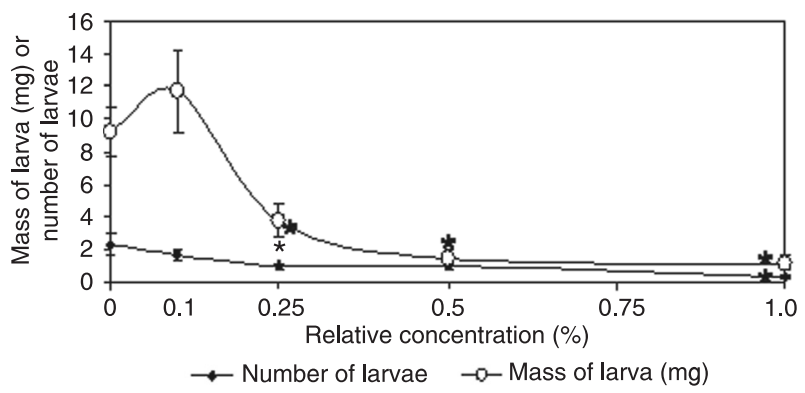

Figure 1. Toxicity of Albizia lebbeck seed coat flour to Callosobruchus maculatus larval development and survival at 20 days after oviposition. The seed coat protein was incorporated into artificial seeds at different relative concentrations $(0.1,0.25,0.5$, and $1.0 \%$ ). Experiments were carried out in triplicate and the data shown are the means $\pm S D$ of these results. ${ }^{*} P<0.05$ compared to control (t-test).

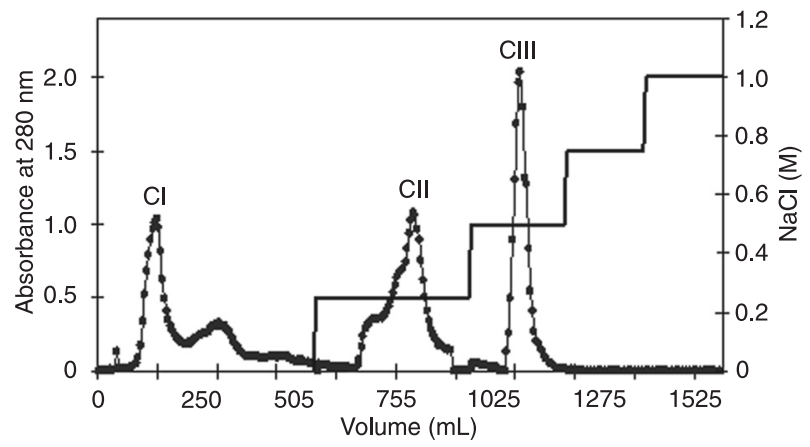

Figure 2. CM-Sepharose ion exchange chromatography $(2.0 \mathrm{x}$ $21.0 \mathrm{~cm}$ ) of Albizia lebbeck seed coat proteins previously precipitated with ammonium sulfate $(0-90 \%$ saturation) and dissolved in sodium acetate buffer, $\mathrm{pH}$ 5.0. The column was equilibrated and chromatography was developed with $0.1 \mathrm{M}$ sodium acetate buffer, $\mathrm{pH}$ 5.0. The non-retained fraction was eluted with $0.1 \mathrm{M}$ sodium acetate buffer, $\mathrm{pH} 5.0$ ( $\mathrm{Cl}$ fraction) and adsorbed proteins were desorbed with 0.25 and $0.5 \mathrm{M} \mathrm{NaCl}$ (CII and CIII fractions, respectively). 
were incorporated into the larval diet and $\mathrm{Cl}$ was the one with highest toxicity, with 67 and $100 \%$ larval mortality at concentrations of 0.1 and $0.25 \%$, respectively (Figure $3 \mathrm{~A}$ ). In addition, we noticed that larval death can happen either before or after hatching (Figure 3B, Panels a-d). When the larval development on natural seeds of $A$. lebbeck and $V$. unguiculata (C. maculatus-host seeds) was monitored, during the initial 6 days after oviposition no morphological differences in larval development were observed between the two seeds (Figure 3B, Panels e-j). Egg content was clear and larvae were virtually formed by the fifth day, when the larvae started to hatch and perforate the seed coat (Figure 3B, Panels e,f). Although they stayed alive for up to 16 days when feeding on $A$. lebbeck (Figure 3B, Panel g), C. maculatus larvae were unable to reach the cotyledonary tissue (Figure 3B, Panel h). On the other hand, C. maculatus larvae were able to reach and intensively feed on the $V$. unguiculata cotyledons by the 6th day after oviposition (Figure 3B, Panels i,j).

Although $\mathrm{Cl}$ administration resulted in a clear reduction of larval counts, the body weight of surviving individuals was apparently unaffected (Figure 3C). CII and CIII were also toxic at $1 \%$, both showing a $67 \%$ mortality rate (Figure $3 \mathrm{~A}$ ) and $\mathrm{CIII}$ also reduced larval body weight by $77.2 \%$ (Figure $3 C)$. Therefore, these results suggest that A. lebbeck seed coat has physicochemically distinct sets of toxic proteins. Due to its higher toxic potential against $C$. maculatus, $\mathrm{Cl}$ was elected for additional characterization experiments.

Cl was submitted to Sephacryl S-100 gel filtration chromatography, resulting in three fractions (SI, SII, and SIII; Figure 4A). Due to its high abundance, we chose $\mathrm{SI}$ for further experiments. When the SI protein profile was examined by SDS-PAGE, three major bands with molecular masses between 50 and 40 kDa (Figure 4B) were demonstrable. These three major bands were cut out, subjected to trypsin digestion and MS analysis. The results showed that two peptides originated from bands 1 and 8 were derived from band 3 (Table 1). The sequences obtained were analyzed by BLAST in order to identify the protein. The peptides were identified as components of vicilin from $V$. unguiculata (ID GenBank emb|CAP19902.1|) and V. radiata 8S globulin (ID GenBank ABG02260). Colcontrol ( $t$-test). lectively, the peptides account for approximately $24.7 \%$ of the $V$. radiata $8 S$ protein and $25.9 \%$ of $V$. unguiculata vicilin sequences. No peptide was obtained from band 2 (45-kDa
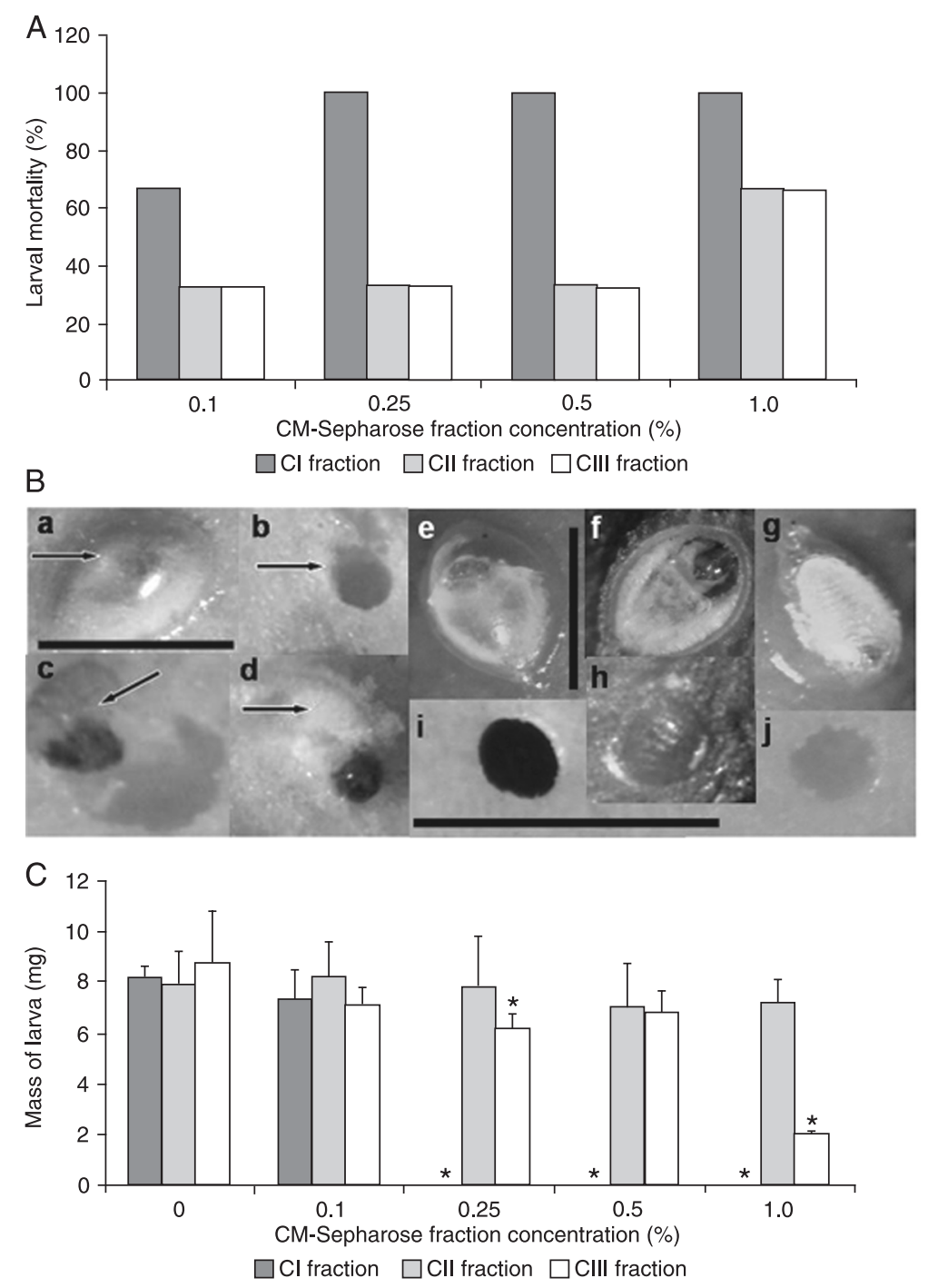

Figure 3. Toxicity of flour and of the $\mathrm{Cl}$ fraction prepared from Albizia lebbeck seed coat to Callosobruchus maculatus larvae. $A$ and $B$, Larval mortality. B, a-d: larval mortality in artificial seeds containing the $\mathrm{Cl}$ fraction (arrows). a: the larva died inside the egg; $b$ : perforation of artificial seed; $c$ and $d$ : dead larvae found inside the artificial seed. e-j: development of larvae on natural $A$. lebbeck and Vigna unguiculata seeds. e: larva inside the egg on the 5th day after oviposition; $f$ : inferior surface of the egg on the 5th day after oviposition; $g$ : larva inside the egg on the 16th day after oviposition; $h$ : A. lebbeck seed coat partially perforated on the 16th day after oviposition; $i$ : hole across the host seed coat from $V$. unguiculata on the 6th day; $j$ : hole on the $V$. unguiculata cotyledon surface on the 6 th day after oviposition. The bar inside Panel a indicates magnification for Panels $a-d$. The bar inside Panel e indicates magnification for Panels e-g. The bar inside Panels $h / i$ indicates magnification for Panels $h-j$. C, Larval mass at 20 days after oviposition. The seed coat fraction was incorporated into artificial seeds at different concentrations $(0.1,0.25,0.5$, and $1.0 \%)$. Experiments were done in triplicate and the data shown are the means $\pm S D$ of these results. ${ }^{*} P<0.05$ compared to 
region). The peptide sequences REQQQQQQEESWE VQRY and RLHEITPEKNPQLRD obtained from protein band 3 were analyzed using the Scaffold $3^{\mathrm{TM}}$ software and the results showed a peptide identification probability of $95 \%$ with V. unguiculata vicilin (ID GenBank 160332746).

We used a computational strategy based on BLAST (21) to identify homologs in the nr database (see Methods for details). Although the peptides sequenced from each band were totally different from each other, the hit lists from the two bands had an extremely high overlap (more than $96 \%$ of the BLAST hits were shared by the bands). Therefore, our results strongly suggest that the two bands are isoforms of the same gene (or extremely close paralogs), and hence we merged the results. The combined list is dominated by vicilins and vicilin-like proteins (e.g., gis 160332746 and 145207915), which were extracted from the $\mathrm{nr}$ database, clustered using blastclust and aligned [data shown at (http://dl.dropbox.com/u/7886304/supplements/BJMBR-Souza2012/BJMBR-SouzaMSA.pdf)]. We extracted taxonomic information for all the hits and found that all the detected homologs were from the Tracheophyta clade (vascular plants), encompassing homologs in the basal vascular plant Selaginella moellendorffii (Lycopodiophyta), the fern Matteuccia struthiopteris, conifers, various monocots (e.g., Oryza sativa and Zea mays) and eudicots (e.g., Vitis vinifera, Phaseolus vulgaris and Glycine max) [data shown at (http://dl.dropbox.
com/u/7886304/supplements/BJMBR-Souza2012/BJMBRSouza-MSA.pdf)]. Although homologs could be detected in such diverse major groups, our results indicate a proliferation of vicilins in eudicots, which is coherent with their prominent nutritional roles in such these seeds.

The SI fraction showed strong toxicity to $C$. maculatus larval development. At a concentration of $0.1 \%$, larval mass was reduced from $8.1 \pm 1.7$ (mass of control larvae) to 1.8 $\pm 0.5 \mathrm{mg}$, which corresponds to a decrease of $78 \%$ (data not shown).

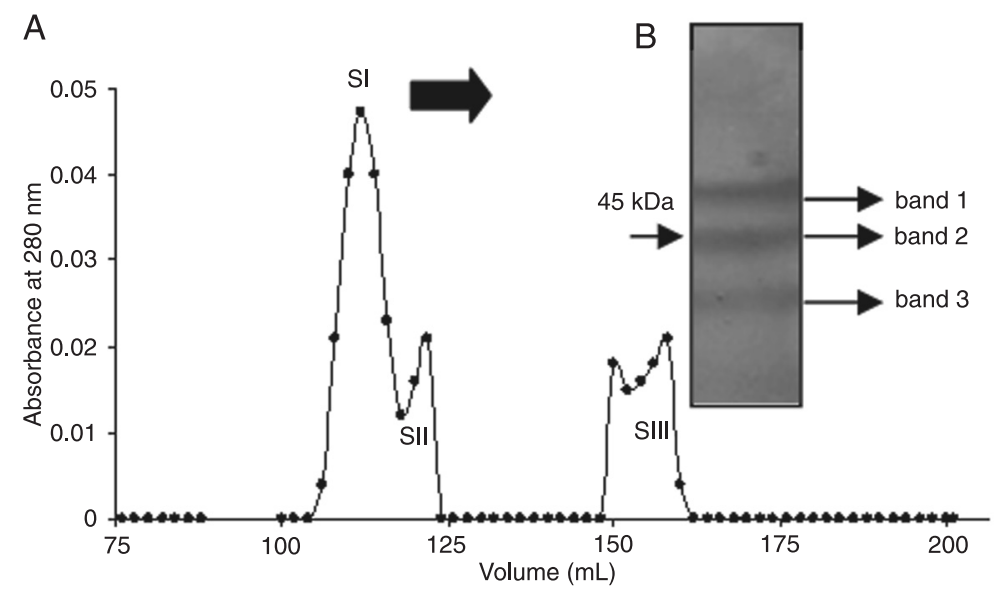

Figure 4. A, Sephacryl S-100 gel filtration chromatography of the $\mathrm{Cl}$ fraction of Albizia lebbeck seed coat previously obtained by CM-Sepharose chromatography resulting in three fractions (SI, SII, and SIII). The column was equilibrated and developed with $50 \mathrm{mM}$ potassium phosphate buffer, pH 7.8. B, SDS-polyacrylamide gel electrophoresis of the SI fraction (106 to $116 \mathrm{~mL}$ ).

Table 1. Mass spectrometry analysis of the peptides from the fraction of Albizia lebbeck seed coat obtained by Sephacryl S-100 gel filtration chromatography (SI fraction).

\begin{tabular}{|c|c|c|c|}
\hline \multirow[t]{2}{*}{ Spot No. } & \multirow[t]{2}{*}{ Peptide sequence } & \multicolumn{2}{|c|}{ Protein accession number and Blast bit score* } \\
\hline & & Vigna radiata $8 S$ globulin ABG02260 & Vigna unguiculata vicilin emb|CAP19902.1| \\
\hline \multirow[t]{2}{*}{ Band 1} & KQIQNLENYRV & 36.3 & 40.1 \\
\hline & RIPAGTTFFLVNPNDNDNLRI & 63.0 & 54.5 \\
\hline \multirow[t]{8}{*}{ Band 3} & RWFHTLFRN & 36.3 & 40.1 \\
\hline & KIPAGTTFFLVNPDDNENLRI & 71.0 & 61.7 \\
\hline & RAILTLVNPDGRD & 41.4 & 43.9 \\
\hline & KQIQNLENYRV & 36.3 & 40.1 \\
\hline & RGQNNPFYFDSDRW & 45.6 & 52.8 \\
\hline & RLHEITPEKNPQLRD & 42.6 & 52.8 \\
\hline & REQQQQQQEESWEVQRY & 53.2 & 62.2 \\
\hline & KLAIPVNNPHRF & 40.1 & 40.1 \\
\hline
\end{tabular}

*Bit scores were computed by aligning the MS peptides against the Vigna radiata 8S globulin protein ABG02260.1 (454 amino acids) and Vigna unguiculata vicilin protein (433 amino acids) using BLAST. Collectively, the peptides encompass approximately $24.7 \%$ of the $V$. radiata $8 S$ protein and $25.9 \%$ of $V$. unguiculata vicilin. We used a $90 \%$ threshold for query coverage and 35 bit score (BLAST) to map the peptides on the vicilin and vicilin-like proteins. 


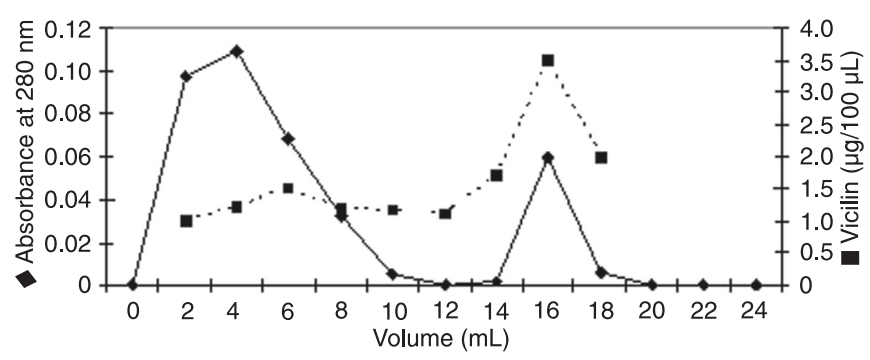

Figure 5. Chitin-binding affinity of Albizia lebbeck seed coat SI protein fraction and quantification of vicilin-like proteins in the non-retained and adsorbed chitin fractions (desorbed with $0.1 \mathrm{M} \mathrm{HCl}$ ).

The vicilin concentration in the SI fraction $(1.4 \mu \mathrm{g} / \mathrm{mg})$ was $~ 5.6$-fold higher than the one found in the $\mathrm{Cl}$ fraction that was $0.25 \mu \mathrm{g} / \mathrm{mg}$ (data not shown). In addition, proteins from the SI fraction also showed strong chitin-binding activity and, after desorption with $0.1 \mathrm{M} \mathrm{HCl}$, were recognized by anti-vicilin antibodies (Figure 5).

\section{Discussion}

Before reaching the cotyledons, bruchid larvae must pass through the seed coat, which may pose not only a physical, but also a chemical toxic barrier to counter the penetration process $(10,28)$. For instance, Acanthoscelides obtectus larvae were unable to penetrate $P$. lunatus seed coats (29) and only $50 \%$ of them penetrated $P$. vulgaris teguments (30). The seed coat of Vicia faba prevented the penetration of about $55 \%$ of the Callosobruchus chinensis and C. maculatus larvae $(31,32)$.

In the present study, we demonstrated that $C$. maculatus oviposition, hatching and adult development were drastically reduced when the bruchids were grown on $A$. lebbeck seeds.

\section{References}

1. Shewry PR. Plant storage proteins. Biol Rev Camb Philos Soc 1995; 70: 375-426.

2. Muntz K, Belozersky MA, Dunaevsky YE, Schlereth A, Tiedemann J. Stored proteinases and the initiation of storage protein mobilization in seeds during germination and seedling growth. J Exp Bot 2001; 52: 1741-1752.

3. Braun $\mathrm{H}$, Czihal A, Shutov AD, Baumlein H. A vicilin-like seed protein of cycads: similarity to sucrose-binding proteins. Plant Mol Biol 1996; 31: 35-44.

4. Baumlein H, Braun H, Kakhovskaya IA, Shutov AD. Seed storage proteins of spermatophytes share a common ancestor with desiccation proteins of fungi. J Mol Evol 1995; 41: 1070-1075.

5. Gomes VM, Okorokov LA, Sales MP, Fermandes KV, Rose TL, Xavier FJ. Vicilin storage proteins inhibit yeast growth and glucose stimulated acidification of the medium by cells. Folia Microbiol 1997; 42: 224.

6. Sales MP, Pimenta PP, Paes NS, Grossi-de-Sa MF, Xavier-
A. lebbeck seed coat flour was shown to be toxic to the larvae, causing considerable lethality and weight loss of 20-day-old larvae. After several purification steps, we obtained a highly toxic vicilin-rich sample that was subsequently shown to have strong chitin-binding activity, with consequent toxicity of certain vicilins to chitin-containing structures in the insect midgut epithelium and fungal cell walls $(5,8,12-14,33)$. It has been hypothesized that particular plant chitin-binding proteins can adhere to insect PMs, interfering with their normal functions and affecting nutrient absorption (12). In addition, chitin-binding vicilins from several plants have been demonstrated to be toxic to several species of insects and fungi $(5,8,13,14,34)$. However, it has also been reported that intact vicilin and vicilin-derived peptides are absorbed by the insect's intestinal tract and incorporated into internal organs and eggs $(7,35)$.

Distinct seeds are naturally predated by diverse bruchids, e.g., V. unguiculata by C. maculatus and Phaseolus by Zabrotes subfasciatus. This relative specificity and dietary preferences are molded by an evolutionary arm race between the insect and plant species (36). Taken together, our results and previous ones suggest that vicilin toxicity might be a major player in such evolutionary phenomenon and could thus be manipulated in plant engineering strategies aiming to enhance seed resistance to predators. However, the mechanism of toxicity of vicilins and their respective detoxification strategies by insects are yet to be described.

\section{Acknowledgments}

Research supported by FAPERJ, CNPq, and Universidade Estadual do Norte Fluminense Darcy Ribeiro.

Filho J. Vicilins (7S storage globulins) of cowpea (Vigna unguiculata) seeds bind to chitinous structures of the midgut of Callosobruchus maculatus (Coleoptera: Bruchidae) larvae. Braz J Med Biol Res 2001; 34: 27-34.

7. Uchoa AF, DaMatta RA, Retamal CA, Albuquerque-Cunha JM, Souza SM, Samuels RI, et al. Presence of the storage seed protein vicilin in internal organs of larval Callosobruchus maculatus (Coleoptera: Bruchidae). J Insect Physiol 2006; 52: 169-178.

8. Paes EV, Uchoa AF, Pinto MST, Silva CP, Fernandes KVS, Oliveira AEA, et al. Binding of Vigna unguiculata vicilins to the peritrophic membrane of Tenebrio molitor affects larval development. Entomol Exp Appl 2008; 129: 11-17.

9. Macedo MLR, Andrade LBD, Moraes RA, Xavier-Filho J. Vicilin variants and the resistance of Cowpea (Vigna unguiculata) seeds to the Cowpea Weevil (Callosobruchus maculatus). Comp Biochem Physiolo, C - Pharmacol Toxicol Endocrinol 1993; 105: 89-94. 
10. Oliveira AEA, Machado OLT, Gomes VM, Neto JX, Pereira $A C$, Vieira JGH, et al. Jack bean seed coat contains a protein with complete sequence homology to bovine insulin. Protein Peptide Lett 2011; 6: 15-21.

11. Moraes RA, Sales MP, Pinto MS, Silva LB, Oliveira AE, Machado OL, et al. Lima bean (Phaseolus lunatus) seed coat phaseolin is detrimental to the cowpea weevil (Callosobruchus maculatus). Braz J Med Biol Res 2000; 33: 191-198.

12. Uchoa AF, de Miranda MR, de Souza AJ, Gomes VM, Fernandes KV, Lemos FJ, et al. Toxicity of hydrolyzed vicilins toward Callosobruchus maculatus and phytopathogenic fungi. J Agric Food Chem 2009; 57: 8056-8061.

13. Mota AC, DaMatta RA, Lima FM, Silva CP, Xavier-Filho J. Cowpea (Vigna unguiculata) vicilins bind to the peritrophic membrane of larval sugarcane stalk borer (Diatraea saccharalis). J Insect Physiol 2003; 49: 873-880.

14. Yunes ANA, de Andrade MT, Sales MP, Morais RA, Fernandes KVS, Gomes VM, et al. Legume seed vicilins (7S storage proteins) interfere with the development of the cowpea weevil (Callosobruchus maculatus (F)). J Sci Food Agr 1998; 76: 111-116.

15. Merzendorfer $\mathrm{H}$, Zimoch L. Chitin metabolism in insects: structure, function and regulation of chitin synthases and chitinases. J Exp Biol 2003; 206: 4393-4412.

16. Terra WR. The origin and functions of the insect peritrophic membrane and peritrophic gel. Arch Insect Biochem Physiol $2001 ; 47: 47-61$

17. Lam SK, Ng TB. First report of an anti-tumor, anti-fungal, anti-yeast and anti-bacterial hemolysin from Albizia lebbeck seeds. Phytomedicine 2011; 18: 601-608.

18. Babu NP, Pandikumar $P$, Ignacimuthu S. Anti-inflammatory activity of Albizia lebbeck Benth., an ethnomedicinal plant, in acute and chronic animal models of inflammation. J Ethnopharmacol 2009; 125: 356-360.

19. Laemmli UK. Cleavage of structural proteins during the assembly of the head of bacteriophage T4. Nature 1970; 227: 680-685.

20. Shevchenko A, Wilm M, Vorm O, Mann M. Mass spectrometric sequencing of proteins silver-stained polyacrylamide gels. Anal Chem 1996; 68: 850-858.

21. Altschul SF, Madden TL, Schaffer AA, Zhang J, Zhang Z, Miller W, et al. Gapped BLAST and PSI-BLAST: a new generation of protein database search programs. Nucleic Acids Res 1997; 25: 3389-3402.

22. Edgar RC. MUSCLE: multiple sequence alignment with high accuracy and high throughput. Nucleic Acids Res 2004; 32: 1792-1797.

23. Stajich JE, Block D, Boulez K, Brenner SE, Chervitz SA, Dagdigian $C$, et al. The Bioperl toolkit: Perl modules for the life sciences. Genome Res 2002; 12: 1611-1618.

24. Sayers EW, Barrett T, Benson DA, Bolton E, Bryant SH,
Canese K, et al. Database resources of the National Center for Biotechnology Information. Nucleic Acids Res 2011; 39: D38-D51.

25. Bridge PD, Sawilowsky SS. Increasing physicians' awareness of the impact of statistics on research outcomes: comparative power of the $t$-test and and Wilcoxon Rank-Sum test in small samples applied research. J Clin Epidemiol 1999; 52: 229-235.

26. Engvall E, Perlmann P. Enzyme-linked immunosorbent assay (ELISA). Quantitative assay of immunoglobulin G. Immunochemistry 1971; 8: 871-874.

27. Hackman RH, Goldberg M. New substrates for use with Chitinases. Anal Biochem 1964; 8: 397-401.

28. Silva LB, Sales MP, Oliveira AE, Machado OL, Fernandes $\mathrm{KV}$, Xavier-Filho J. The seed coat of Phaseolus vulgaris interferes with the development of the cowpea weevil [Callosobruchus maculatus (F.) (Coleoptera: Bruchidae)]. An Acad Bras Cienc 2004; 76: 57-65.

29. Thiery D. Hardness of some fabaceous seed coats in relation to larval penetration by Acanthoscelides obtectus (Say) (Coleoptera, Bruchidae). J Stored Prod Res 1984; 20: 177181.

30. Thiery D, Jarry M, Pouzat J. To penetrate or not to penetrate - a behavioral choice by bean beetle 1st instar larvae in response to Phaseolus vulgaris seed surface quality. J Chem Ecol 1994; 20: 1867-1875.

31. Boughdad A, Gillon Y. Cagnepain C: effect of the ripe seed husks of vicia faba on the larval development of Callosobruchus maculatus. Entomol Exp Appl 1986; 42: 219-223.

32. Desroches P, Elshazly E, Mandon N, Duc G, Huignard J. Development of Callosobruchus chinensis (L) and C. maculatus ( $F$ ) (Coleoptera, Bruchidae) in seeds of vicia faba $L$ differing in their tannin, vicine and convicine contents. $J$ Stored Prod Res 1995; 31: 83-89.

33. Sales MP, Gomes VM, Fernandes KV, Xavier-Filho J. Chitinbinding proteins from cowpea (Vigna unguiculata) seeds. Braz J Med Biol Res 1996; 29: 319-326.

34. Moura FT, Oliveira AS, Macedo LL, Vianna AL, Andrade LB, Martins-Miranda AS, et al. Effects of a chitin-binding vicilin from Enterolobium contortisiliquum seeds on bean bruchid pests (Callosobruchus maculatus and Zabrotes subfasciatus) and phytopathogenic fungi (Fusarium solani and Colletrichum lindemuntianum). J Agric Food Chem 2007; 55: 260-266.

35. Souza SM, Uchoa AF, Silva JR, Samuels RI, Oliveira AE, Oliveira EM, et al. The fate of vicilins, 7S storage globulins, in larvae and adult Callosobruchus maculatus (Coleoptera: Chrysomelidae: Bruchinae). J Insect Physiol 2010; 56: 11301138.

36. Vermeij GJ. Evolution and escalation: an ecological history of life. Princeton: Princeton University Press; 1987. 